Department of English Studies

radic.bojanic@ff.uns.ac.rs

\title{
TEACHERS' ATTITUDES TOWARDS AUTHENTIC MATERIALS IN TEACHING ANGLOPHONE CULTURE TO YOUNG LEARNERS ${ }^{1}$
}

\begin{abstract}
The paper aims at presenting the current attitudes and opinions of teachers who teach the English language to young learners in public elementary schools in Serbia, with special reference to the use of authentic materials in teaching culture. First, a theoretical framework for teaching culture to young learners with authentic materials is established, which is followed by the results of the research based on a focus group interview, where the focus group consisted of teachers who taught English to young learners in public elementary schools. In addition to revealing the informants' attitudes and beliefs, the results could implicitly point to the teachers' classroom practice and indicate professional areas that could be improved through professional development seminars.
\end{abstract}

Key words: culture, authentic materials, young learners, teaching, English language.

\section{STAVOVI NASTAVNIKA PREMA UPOTREBI AUTENTIČNIH MATERIJALA U NASTAVI ANGLOFONE KULTURE NA RANOM UZRASTU}

APSTRAKT: Cilj rada je da predstavi trenutne stavove i mišljenja nastavnika engleskog jezika na ranom uzrastu koji rade u državnim osnovnim školama, sa posebnim osvrtom na upotrebu auteničnih materijala u nastavi kulture. U radu se najpre izlaže teorijski okvir vezan za nastavu kulture stranog jezika na ranom uzrastu, kao i za uvođenje autentičnih materijala, a potom se izlažu rezultati istraživanja zasnovanog na intervjuu sprovedenom $u$ fokus grupi. Fokus grupa se sastojala od nastavnika koji su predavali engleski na ranom uzrastu u državnim školama. Pored toga što otkriva stavove i uverenja ispitanika, rad implicitno opisuje nastavne prakse i ukazuje na stručne oblasti koje bi mogle da se unaprede kroz seminare za profesionalno usavršavanje nastavnika.

Ključne reči: kultura, autentični materijali, učenici ranog uzrasta, nastava, engleski jezik.

\footnotetext{
${ }^{1}$ The paper is the result of research conducted within project no. 01600 funded by the Ministry of Education, Science and Technological Development of the Republic of Serbia.
} 


\section{INTRODUCTION}

It is never too early to start developing cultural awareness, so the introduction of cultural content into the classrooms of young learners is an advisable step. Cultural diversity is an important concept to grasp during childhood because this understanding will enable children to embrace and value the things that make each person or group of people different. Children notice differences and taking time to teach what is important to each culture can help foster acceptance and understanding (Johnson 2009). There are many ways to introduce culture into the young learners' classroom, such as incorporating important elements of cultural celebrations (Mayesky 2008) or introducing the arts (Tillman and Belgrave 2001). The former uses the experiential approach to teach pupils about the different foods, music, art and songs that have value in different cultures, which enables children to learn why cultures behave in certain ways and believe certain things, because they have a chance to actively participate in the celebration. The latter, which relies on the arts, employs creative and fun activities to teach children about what is important to people of different cultures. This idea is further developed by Gay (2000), who suggests using books and videos to help make different cultures come alive for pupils, especially because of the visual aspect of the input. She asserts that if pupils can visualize how other people live, they are more likely to understand more about different cultures. Seeing pictures in books or watching documentaries about other groups of people will enable pupils to experience what is significant to cultures other than their own. This is important because an increased awareness of different groups of people can help eliminate ethnic stereotypes and lead to greater acceptance.

The manner of implementing (authentic) cultural material and introducing cultural content highly depends on the learners' age because of the differences in life experience and also because of various cognitive abilities that young learners, teenagers, young adults or adults have. This paper focuses on the work with young learners because they are the least experienced in terms of contact with other cultures and are just starting to develop more complex cognitive skills that allow them to comprehend the characteristics of other cultures. In order to find out how culture is dealt with in the young learners' classroom, the research focuses on the current attitudes and opinions of teachers who teach the English language to young learners in public elementary schools in Serbia, with special reference to the use of authentic materials in teaching culture. An interview with a focus group intends to reveal the informants' attitudes and beliefs and the results implicitly point to the 
teachers' classroom practice and indicate professional areas that could be improved through professional development seminars.

\section{AUTHENTIC MATERIALS}

Corbett (2003: 42) defines authentic materials as any written or spoken text that has not been produced for the purposes of teaching and learning a language. In the communicative approach, the use of such materials is thought to be extremely valuable. Kramsch (1993: 177) explains that the term "authentic" has been used as a reaction against the prefabricated artificial language used in textbooks and instructional dialogues. It refers to the way language is used in a non-pedagogic, natural communication. According to Larsen-Freeman (2000: 132-133), authentic materials are often used to bridge the gap between classroom learning and the outside world. In order for students to experience natural language, they are exposed to authentic material in the communicative classroom.

Arguing for the use of authentic materials, Kramsch (1993: 177) debates on whether we actually teach culture whilst teaching language and what it means. The extent to which authenticity can be reached in teaching language in such conditions is questionable, since the learning of a language in a classroom is a highly artificial process, devised to fulfill the needs of a standardized classroom.

Kilickaya (2004) claims that cultural content which is introduced through authentic materials should provoke interest in students, not only in the foreign language, but in the foreign culture as well. The purpose of using authentic materials in class, besides bringing the foreign culture into the classroom, is to conduct a communicative method in class and allow students to discuss cultural similarities and differences through meaningful activities. This provides a sense of learning a foreign language and finding out about a foreign culture with a purpose. In addition to that, authentic materials might be useful as a break from a routine and a way to bring culture to learners so they can experience it.

Hwang (2005: 6-8) observes that when introducing authentic materials, teachers should be cautious and not cause frustration in students. He also states that current popular authentic materials, which include best-selling stories, newsmagazines, talk-shows, TV news, etc., might be a better choice since they bear relevance to the students' 'here and now'. Hwang (2005: 6-8) asserts that the teacher's main objective should be to develop love for authentic materials in students, because once they are hooked on the authentic materials, the process of natural acquisition begins to set in. Most importantly, authentic materials provide a day-to-day contact with the foreign language, which is crucial for learning the 
language and is not available for the students when learning a foreign language (Hwang 2005: 6-8).

However, Corbett (2003) is not convinced that authenticity is achieved by the use of authentic materials in the classroom. He argues that, even though a native speaker in real-life and a student in the classroom may read the same newspaper, they do not use it in the same way. In fact, the student's over-analysis of the newspaper takes away the authenticity. While this sounds logical, Corbett (2003: 42) also adds a contradicting argument that even though the experience of using authentic materials in the classroom might be different from the one in reallife situations, the learner is still not a native speaker but an intercultural observer: rather than being a part of the L2 culture, the learner is distanced from the L2 culture. In order to establish a successful intercultural classroom, not all materials need to be authentic. However, an intercultural classroom results in the broadening of input which facilitates learning.

The reasons for teaching $\mathrm{L} 2$ culture with authentic materials are numerous. However, it is wise to consider both its benefits and drawbacks, as Martinez (2002: 1) explains (see Table 1).

\begin{tabular}{ll}
\hline ADVANTAGES & DISADVANTAGES \\
\hline $\begin{array}{l}\text { Authentic materials encourage learning for } \\
\text { pleasure, since often they focus on topics of } \\
\text { interest for students. }\end{array}$ & $\begin{array}{l}\text { Authentic materials may be overly culturally } \\
\text { based, so that they are incomprehensible for } \\
\text { a learner who is outside of the language } \\
\text { community. }\end{array}$ \\
\hline $\begin{array}{l}\text { Authentic materials keep students informed } \\
\text { of what goes on in the world. }\end{array}$ & $\begin{array}{l}\text { The vocabulary might be redundant for the } \\
\text { current students' needs. }\end{array}$ \\
\hline $\begin{array}{l}\text { Students are exposed to real discourse. } \\
\text { Authentic materials produce a sense of } \\
\text { achievement in students. }\end{array}$ & $\begin{array}{l}\text { Variety in accents can confuse the learner. } \\
\text { the same material is recyclable in many } \\
\text { different ways for different purposes. }\end{array}$ \\
\hline
\end{tabular}

Both students and teachers witness current language change.

Different materials cover different language styles which cannot be found in conventional textbooks.

Table 1. Martinez's (2002) view on advantages and disadvantages of teaching with authentic materials 
Another advantage of using authentic materials over the course book material is noted by Hwang (2005: 6):

English textbooks, authored by educators rather than professional writers, tend to carry a preaching and patronizing tone. The authors and their readers are inherently not on the equal footing. The textbook English, written from the perspective of talking to a "foreign" (namely, "outsider") audience, can hardly avoid contrivance.

As already stated in the introduction, the application and use of authentic material in teaching culture to young learners is more complex and demands a careful consideration and planning, which is elaborated in the following section.

\section{YOUNG LEARNERS AND AUTHENTIC MATERIALS}

Especially with young learners, teachers may think that authentic materials will confuse pupils and thus choose to avoid them because of many reasons listed in the previous section. However, authentic materials can be used in the young learners' classroom and the success of the class depends on the teachers' creativity and willingness to use them. There are numerous ways of employing authentic materials in teaching young learners and they depend on the teacher's visions, classroom needs as well as the learners' preferences. The teacher should primarily get to know the learners he/she teaches and then include particular authentic materials that will be appealing to them. Therefore, it can be said that teaching young learners with authentic materials is influenced by many factors.

Despite the fact that it is a complicated and painstaking process, it must not be rejected by teachers altogether. On the contrary, they should always strive to come up with innovative ways of teaching and this might as well include teaching with authentic materials. The age and level at which it is possible to conduct a language class with authentic materials is debatable and, while many teachers might consider it to be a privilege of mature and advanced learners, using authentic materials with young learners is also possible and just as effective.

According to Smith (1997), in addition to authentic materials, teaching language and culture to young learners can also be done by using realia. Smith (1997) gives a terminological distinction between 'realia' and 'authentic materials' explaining that realia is used to refer to real-life objects such as postcards, objects, items, etc., whereas newspapers, video material, audio recordings of radio shows and other verbal materials are considered to be authentic materials. Therefore, it can be logically deduced that realia is supposed to be used with younger learners and authentic materials are supposed to be used with older learners. However, due 
to the fact that we consider children's storybooks, songs and films part of the category of authentic materials rather than the category of realia, we have decided to use only the term 'authentic materials' in order to cover all sorts of materials which are not intended to be used as teaching material, but nonetheless can be used as such in the foreign language classroom. To sum up, the term 'authentic materials' in this paper will cover storybooks, films, songs, postcards, posters, toys, objects and items, packaging and labeling, books, audio and video materials, etc.

It can be seen that all these suggestions partially or fully rely on the use of authentic materials from L2 in the young learners' classroom. In the paper we focus on this issue from the teachers' perspective investigating the extent to which the teachers from the focus group use this kind of materials and how, and we are relying on the qualitative method of interview to collect the necessary data.

\section{RESEARCH METHODOLOGY}

\subsection{Research method and research design}

The paradigm in which the research was conducted is qualitative research, which focuses on the process, understanding and meaning. In this case, the researcher is the primary instrument of data collection and analysis, the process itself is inductive and the product is richly descriptive. The method employed is the interview, whereby the researcher is an immediate instrument and participant in the process of research. We opted for this approach in order to provide a better insight into the research question, which is possible due to the immediate contact with interviewees.

Tripković (2007: 201) claims that the opinions of interviewees are not necessarily objective descriptions of a situation, do not have to be truthful and, therefore, must be deeply analyzed. Interview is a valuable method mainly due to the fact that during the interview the interviewer has a unique opportunity to achieve an immediate contact with interviewed informants and gain insight into their overall behavior. Other advantages of conducting an interview are that during an interview the interviewer can check the comprehension of the question by the informant, rephrase the question or provide an additional explanation if needed.

This technique also has its disadvantages: candidates are not anonymous, which can affect the truthfulness of their statements. A way to avoid problems is to choose the type of the interview adequate for each given situation: standardized or informal interview. In a standardized interview the questions are formulated prior the interview, whereas in the informal interview only general topics of 
conversation are chosen prior the interview. Other than that, the conversation might go on in any direction (Tripković 2007: 201).

This paper is based on a research conducted in September 2018 regarding teachers' attitudes towards using authentic materials in their young learners' language classrooms. The research was conducted in the form of an interview with the teachers of English employed in public schools in Serbia and the informants who were interviewed are all teachers of English, who are, or have been, recently employed in public schools to teach English from the $1^{\text {st }}$ to $6^{\text {th }}$ grades. The data was collected through the focus group interview, which was first recorded and then transcribed. Subsequently, the transcriptions were analyzed by the method of content analysis and the information that the teachers gave was categorized with respect to the questions which were used as a guideline for conducting the interview.

\subsection{Profile of interviewees}

Although for the purposes of this research specific details about interviewees are not presented and are not relevant, some general information will be elaborated in this section. Firstly, all of the interviewees are currently employed or have been recently employed in public elementary schools as teachers of the English language. They teach or have taught English from the $1^{\text {st }}$ to the $6^{\text {th }}$ grades. Five out of six interviewed teachers are currently employed at teaching positions in public elementary schools, whereas only one teacher is no longer employed.

The focus group interviewed in this research consisted of five female teachers and one male teacher. The informants differ in their teaching experience: four out of six teachers have been teaching over a decade, whereas two of the interviewed candidates have taught for under or just over a year. As for the teaching environment, two of the interviewed teachers teach in an urban environment, whereas four teachers teach in a rural environment. Five out of six interviewed candidates live and work in Vojvodina, and only one teacher is from Central Serbia.

\section{RESEARCH RESULTS AND DISCUSSION}

The answers to the interview questions were divided into four categories with respect to the questions which were used as a guideline for conducting the interview. These categories concern the teachers' willingness to teach culture, teachers' teaching conditions, teachers' opinions and knowledge about authentic 
materials as well as their personal assessment of students' knowledge concerning Anglophone culture. Each of these categories was analyzed in detail in the following sections.

\subsection{Teachers' willingness to teach culture}

Firstly, we aimed to investigate the teachers' attitudes towards Anglophone culture and we found that all the interviewed teachers think culture is an absolutely important aspect of a foreign language and therefore plays an important part in language teaching. The reasons and explanations given generally reflect the belief that students should know more about the language they learn and its cultural background.

Several reasons that the teachers listed reflect the importance of knowing where the foreign language comes from. The teachers believe culture should be taught because language reflects culture of the people who speak that particular language. Moreover, the interviewed teachers think culture is an important aspect of language, as much as four language skills are. Finally, culture enables learners to get the complete picture about the language and all of the interviewed candidates agree that teachers should teach culture along with teaching language.

When asked if they teach culture as a part of their syllabus with young learners in their schools, five out of six interviewed teachers said that they did and only one teacher admitted she did not teach culture as a part of the syllabus. She explained the lack of cultural content in her lessons by the fact that she was employed for a short amount of time (three months) as a substitute teacher and during that time she had difficulties adjusting to the new situation. Therefore, she did not really devote much time to teaching culture to young learners.

Five out of six interviewed teachers claimed that they generally used additional materials in order to teach culture besides the course book. However, these additional materials regarding culture were also related to what was mentioned in the course book. Moreover, these additional materials usually concerned particular celebrations such as Halloween, Easter, Christmas or New Year. On the other hand, two out of six interviewed teachers admitted to not having enough time to prepare culturally based material and therefore rather used the one presented in the course book. They described preparing such materials as time-consuming in two ways: firstly, it takes a lot of time from the class, which can be spent achieving the aims of the syllabus; and secondly, it takes a lot of time and effort on the part of the teacher in order to find and use such materials in a lesson. The teacher with the least teaching 
experience claimed that she did not have enough time to prepare such teaching materials and did not use them at all.

Five teachers claimed that it is important for teachers to teach culture from an early age. The less experienced teacher admitted that she did not teach culture to young learners because she did not know how to do it. Furthermore, one teacher explained that in her opinion teaching goals such as teaching culture are perhaps overambitious in regular classes, but could be better achieved in English Drama Clubs and English Language Clubs. This teacher believed that it would be the best solution for teaching culture for both learners and their teacher. Whereas this teacher believed that teaching culture should be tied only to activities in certain clubs, another teacher voiced the opinion that cultural units should be adapted and then could be used even with first graders.

As for the importance of teaching culture, all six interviewed candidates agreed that it was important for them as teachers to teach culture to young learners and mainly supported this claim by the fact that language is inseparable from culture. Teachers recognized culture as an integral part of the language because they had contact with foreign languages for a long time, either through learning or teaching them, and therefore they were aware of the role that culture has in language and numerous ways in which it can ease the communication across cultures or, on the other hand, create misunderstandings.

When asked how they taught culture to a class of young learners, five out of six interviewed teachers mentioned using course books and materials which arrived along with the course book, such as CDs, DVDs with video material, flash cards and posters, as the main resources used for teaching culture. In addition, two of six interviewed teachers recognized the need to make cultural comparisons in class when teaching culture and only one teacher recognized the need for such materials to be adapted to young learners' needs and skills. Five out of six interviewed teachers mentioned bringing additional materials such as posters, flags, interviews and other audio and video materials as the resources used in order to teach culture. The least experienced teacher said that she thought it was possible to teach culture to young learners, however she pointed out that she was uncertain how and that she would need guidance from a more experienced teacher in order to achieve such goals.

On the basis of the presented results we can single out two categories of teachers: those who mainly rely on the course book in teaching culture and use additional materials rarely and those who mainly rely on the additional materials in teaching culture and use the course book as a guideline. Four out of six teachers seem to focus mainly on the course book when teaching and use additional materials rarely and for specific occasions, such as celebrations and holidays. The majority of these 
teachers have more experience in teaching, over ten years, and it is somewhat expected that they have a particular routine, and there is one inexperienced teacher, who did not quite cope with bringing additional materials apart from those in the course book. Two of these six teachers, one being less experienced and one more experienced, however, teach culture with additional materials regardless of what has been covered in the course book. We can deduce that there is a problem with teaching culture with additional materials with both more and less experienced teachers. More experienced teachers have grown accustomed to teaching automatically with the help of the course book, they have their own routine and contribute little additional materials to class, while less experienced teachers may encounter obstacles such as inexperience and fear of straying from the syllabus. All in all, we can conclude that the most important factor in teaching culture is not the quality of the course book or the experience of the teacher, but the teacher's enthusiasm to teach culture to young learners. Some teachers have mentioned problems such as lack of time for preparing additional materials, however from the informal conversation we actually learnt that what they lacked the most was enthusiasm.

\subsection{Teachers' attitudes towards teaching conditions}

The second category of data referred to the teaching conditions regarding teaching culture in public schools in Serbia. Firstly, the informants were asked to describe the teaching conditions. Even though they qualified conditions as "nonexistent", "satisfying", "good" and "very good", this seemed to be their subjective opinion, since all of the informants basically had quite similar teaching conditions. In public schools in Serbia every teacher has a CD player, course books and the materials that go along with it (teacher's book, activity book, class CDs, DVDs, posters, flash cards). As for the availability of computers, DVD players and projectors, every teacher had at least access to it although it may not be in their own classroom: three teachers said there was just one classroom with those resources in the entire school and it is important to mention that these teachers worked in rural areas. Also, a teacher who worked in a rural area in Banat mentioned that conditions were better before, there was a computer in every classroom, however technology became outdated and these items were not replaced.

When asked whether it was demanding for them to teach culture in their teaching conditions, four out of six interviewed teachers said that it was not. However, two remaining teachers said that it was demanding and they claimed this was because they had to spend their personal time preparing cultural units, but even 
these teachers said they had some personal satisfaction from the children's reaction to such materials and cultural topics in general.

As for the course books used in teaching, the interviewed teachers used the following course books: Happy House, Happy Street, Project, English Adventure, Discovery English, Primary Colours, and Easy. During the interview we learnt that Anglophone culture in these course books was presented in different ways. Happy House is a course book used for the first and second grades in primary school and, according to the two teachers who use it, there is not much cultural content in them. The only cultural segments are based on everyday routines and holidays such as Easter and Christmas. Happy Street is a course book which follows the Happy House programme. It is used in the third and fourth grades of primary school. According to the two of the interviewed candidates who used it in teaching, in this course book Anglophone culture is presented through separate cultural parts that follow each unit. The teachers who used it claimed that it has more cultural content due to the age of the learner. According to two interviewed teachers who use English Adventure, Anglophone culture is presented in a subtle way: it is narrowed down to mentioning specific cultural customs and simple and subtle representations such as, for example, a typical house in Britain. These course books are used in the first two grades of primary education and because of that they have less explicit cultural units in them. The teacher who used Primary Colours also mentioned that in the first two years of primary education Anglophone culture was introduced in a subtle and unobtrusive way, so some cultural references such as the five o'clock tea were merely mentioned, but the course books used in third and fourth grades presented cultural content more explicitly. As for the course book Discovery English, the interviewee claimed that there were cultural units present, but they were rare. A distinction was made between two varieties of English, British and American English, and there was a section with flags of various countries, but the teacher who used it claimed that culture was perhaps not presented in the best way in this course book. The course books named Project, according to two of the interviewed informants, have enough cultural references which are then used in teaching through comparison between the cultural customs and traditions in Serbia and in Anglophone countries. Finally, the teacher who used Easy claimed that the book was not interactive enough and therefore uninteresting to young learners. She also stated that cultural points were better presented in the course books used in the third and the fourth grades.

Throughout the interview we noticed that all of the six interviewed teachers consistently claimed that Anglophone culture was better presented from the third grade onwards. In the first two grades the course books offer few cultural points in a subtle and unobtrusive way, whereas the third grade seems to be the turning point for 
introducing more explicit cultural points. This may be explained by the fact that the learners who attend the third grade have finally learnt both the Latin and Cyrillic alphabets and are able to read and write in English, so introducing Anglophone culture to them with written texts is now more possible.

As for additional materials used to teach culture, five out of six teachers claimed that they used additional materials to teach culture even though there were enough cultural points in the course book itself. The main source for obtaining these materials seemed to be the Internet, but two teachers also claimed that additional materials were provided to them by the school, whereas other two teachers mentioned using public libraries or specialized bookstores.

\subsection{Teachers' attitudes towards authentic materials}

When asked if they knew what authentic materials are, all of the interviewees responded positively. Five teachers even claimed they used authentic materials in teaching and two emphasized that they used authentic materials whenever they could in teaching.

During the interview we found out that different teachers were inclined to use different types of authentic materials. Two teachers chose to focus more on visual materials such as posters and pictures when teaching young learners with authentic materials, two mentioned using mainly video and audio materials and only one teacher focused on realia. It is important to note that this merely showed their preferences, not their constant use of the same type of materials. Two teachers also claimed that it depended on the class and pupils' individual preferences, but this use also depends on the teacher and their personal experience, access to authentic materials and other similar factors.

When asked how they came in possession of these authentic materials, all six interviewed teachers again claimed they primarily used the Internet, whereas three teachers claimed they use authentic materials that they had obtained from their own stays in Britain. Two teachers came into possession of these materials through another party, who either brought them those items from abroad or left them this teaching material when they did not need it anymore. One teacher claimed that the Internet was the only source of authentic materials for them since this particular teacher in question had never been to an English speaking country and did not know anyone who would obtain authentic materials for her from abroad.

One of the interviewees said that authentic materials should be used only with older, more competent learners and, consequently, this particular teacher claimed that she did not use authentic materials often because she worked with 
younger pupils. Four teachers claimed they used authentic materials frequently, but three of them also claimed that they taught culture with authentic materials only when the syllabus allowed them to. The same teachers said that sometimes there was not enough time during the class to cover what was planned in the syllabus, but they tried to devote each possible moment to teaching culture with authentic materials or additional materials.

As for the reaction that authentic materials bring out in young learners, all the informants said it was a positive one. Four teachers claimed that it broke the routine in class and the children seemed interested in everything new and unfamiliar, even if they did not quite understand it. One teacher even claimed that he could not decide if young learners' enthusiasm was a genuine interest in the new culture or just enthusiasm of breaking a familiar routine with something new and unfamiliar.

On the basis of the data presented here we can conclude that young learners have a positive reaction to authentic materials, which could, therefore, be used in their classroom. Even if such materials were not adapted to their learning needs and teacher's teaching needs and even if learners had minimal or no comprehension of the authentic materials whatsoever, it can be said with a fair amount of certainty that authentic materials boost young learners' enthusiasm for learning English as a foreign language and break the routine and monotony of regular classes. Surely it is more than sufficient for young learners to experience pleasure in learning the foreign language and, therefore, develop a true interest not only in Anglophone culture, but the English language as well.

\subsection{Teachers' beliefs about students' knowledge regarding Anglophone culture}

During the interview we established that five out of six teachers believed that young learners aged 7 to 12 did not know much about Anglophone culture claiming that nowadays young learners know even less about Anglophone culture than they did ten years ago. The teachers' overall impression was that young learners know some aspects of Anglophone culture, but are not very well acquainted. One teacher commented that sometimes young learners' first contact with Anglophone culture was in class, another claimed that young learners have some knowledge about some cultural aspects, whereas the third one said that young learners seem uninterested in culture. All in all, it seems that young learners' knowledge and interest in Anglophone culture is diverse and depends on various factors.

In connection with that, one informant made an interesting point that some pupils will reject anything that is not a part of Serbian culture, which reflects a high degree of ethnocentrism and may be problematic at such a young age. Five teachers 
believed that family and their attitudes have a great impact on young learners' tolerance and acceptance of different cultures, while the most experienced teacher in the focus group claimed that she was under the impression that parents' lack of interest in different cultures was transferred to children. On the other hand, she asserted that the more the children were in contact with relatives and family friends who lived abroad, the more they would learn about different cultures from a very early age.

The teacher from a rural environment in Central Serbia said that in the setting where she taught there was little or no entertainment, the majority of pupils had no access to the Internet and, therefore, any Anglophone input young learners received was during the English class and they were interested in anything that was presented to them. Two teachers said that pupils find satisfaction in learning about their age groups. In other words, even if they seem uninterested in culture per se, they seem interested in their peers who live abroad and their routines. These same teachers motivated young learners to compare Anglophone cultures with their own culture as much as possible thus contributing to raised interest and motivation.

Young learners learn about Anglophone culture in school, but according to the teachers, they also learn from their family members, TV, games and the Internet. Two of the interviewees however, claim that even though young learners use the Internet, they do not use it for educational purposes, but rather for social networks and fun. When asked if they encouraged young learners to research Anglophone culture, as many as four teachers responded negatively, listing as some of the reasons their lack of innovation, their opinion that pupils were incapable of such tasks, or the fact that they usually did it in class. Only two teachers stated that they in fact encouraged children to learn more about Anglophone cultures and that they gave them simple assignments to ask parents or gather information from encyclopaedias and the Internet about a particular cultural reference. Towards the end of the interview all six interviewed candidates concluded that they would reinforce cultural research with their pupils in the future.

\section{CONCLUSION}

We chose to investigate this particular subject in order to gain insight into current attitudes of teachers in public schools towards teaching Anglophone culture to young learners with authentic materials. The results support the claim that public school teachers teach Anglophone culture to young learners with authentic materials to a greater or lesser extent, but teachers do not use authentic materials often enough and they do not use them in a variety of ways in which they can be used. This 
situation could be improved if professional development seminars were organized for teachers to show them a variety of ways for implementing authentic materials in class, but also if teachers cooperated and started learning from each other collaboratively. We would also like to point out that authentic materials have proven to be enthusiastically accepted by young learners and can only contribute to the overall quality of teaching. We hope that these results will inspire teachers to use authentic materials often and in various creative ways, which will most likely improve the quality of their classes and be beneficial for learners in the long run.

\section{REFERENCES}

Corbett, J. (2003). An Intercultural Approach to English Language Teaching. Clevedon: Multilingual Matters Ltd.

Hwang, C. C. (2005). Effective EFL Education Through Popular Authentic Materials. Asian EFL Journal 7 (1): 1-12. Accessed on 20 April 2020. <URL: www.asian-efl-journal.com/March_05_ch.pdf >.

Gay, G. (2010). Culturally Responsive Teaching: Theory, Research, and Practice. New York: Teachers College Press.

Gordon, T. (2007). Teaching Young Children a Second Language. Westport: Praeger Publisher.

Johnson, R. G. (2009). A Twenty-First Century Approach to Teaching Social Justice. New York: Peter Lang.

Kilickaya, F. (2004). Authentic Materials and Cultural Content in EFL Classrooms. The Internet TESL Journal X (7). Accessed on 21 April 2020. <URL: iteslj.org/Techniques/Kilickaya-AutenticMaterial>.

Kramsch, C. (1993). Context and Culture in Language Teaching. Oxford: Oxford University Press.

Larsen-Freeman, D. (2000). Techniques and Principles in Language Teaching. Oxford: Oxford University Press.

Martinez, G. A. (2002). Authentic Materials: An Overview. Accessed on 22 April 2020. <URL: www3.telus.net/linguisticsissues/authenticmaterials.html>.

Mayesky, M. (2008). Creative Activities for Young Children. New York: Delmar Cengage Learning.

Meyer, M. (1991). Developing transcultural competence: case studies of advanced foreign language learners, in Mediating languages and cultures: towards an intercultural theory of foreign language education, eds. D. Buttjes \& M. Byram (Clevedon: Multilingual Matters): 136-158. 
Smith, B. (1997). Virtual Realia, The Internet TESL Journal III (7). Accessed on 20 April 2020. <URL: iteslj.org/Articles/Smith-Realia〉.

Tillman, D. and M. Belgrave. (2001). Living Values Activities for Young Adults. Deerfield Beach: HCI.

Tripković, M. (2007). Intervju, u Sociološki rečnik, ur. A. Mimica i M. Bogdanović (Beograd: Zavod za udžbenike).

Biljana B. Radić-Bojanić

Univerzitet u Novom Sadu

Filozofski fakultet, Odsek za anglistiku

\section{STAVOVI NASTAVNIKA PREMA UPOTREBI AUTENTIČNIH MATERIJALA U NASTAVI ANGLOFONE KULTURE NA RANOM UZRASTU}

Sažetak

Stavovi prema nastavi kulture u sklopu časova engleskog jezika na ranom uzrastu su kontradiktorni, naročito zbog malo istraženih metoda i načina implementiranja autentičnih materijala u ovom učioničnom kontekstu. Ova tema je naročito problematična u državnim osnovnim školama iz nekoliko razloga (planovi i programi resornog ministarstva koji ne ostavljaju dovoljno vremena za dodatne aktivnosti, nedostatak resursa i materijala, itd.), te se ovaj rad bavi upravo ciljnom grupom nastavnika koji rade u državnim školama i istražuje njihove stavove prema nastavi kulture na ranom uzrastu sa autentičnim materijalima. Kroz polustrukturisani intervju pokušali smo da ispitamo stavove i mišljenja nastavnika iz fokus-grupe, kao i aktuelne trendove u nastavi engleskog jezika i kulture u državnim školama u Srbiji, pogotovo na ranom uzrastu. Analizom podataka dobijenih putem intervjua pokazali smo da nastavnici koriste autentične materijale u nastavi engleskog jezika na ranom uzrastu, ali da je ta upotreba veoma raznolika i da zavisi od različitih faktora kao što su iskustvo samog nastavnika, dostupnost autentičnih materijala, znanje o tome kako ih upotrebiti u nastavi i sa kojim uzrastom. Sem toga, ustanovili smo da i nastavnici i učenici imaju izrazito pozitivan stav prema ovakvim materijalima i da ih rado koriste, mada smo mišljenja da i ovde ima prostora za unapređivanje nastavne prakse, naročito putem obuke nastavnika.

Ključne reči: kultura, autentični materijali, učenici ranog uzrasta, nastava, engleski jezik.

Received: 17 June 2020

Accepted: 16 September 2020 